\title{
Pelindungan Hukum Atas Perbuatan Adaptasi Naskah Yang Dilakukan Oleh Sutradara Dalam Pertunjukan Teater
}

\author{
Ahmad Muhsin \\ Fakultas Hukum Universitas Islam Indonesia Yogyakarta Indonesia \\ Jln. Cik Di Tiro No. 1 Yogyakarta Indonesia \\ ahmadmuhsin77@gmail.com
}

\begin{abstract}
This study aims to analyze the protection of copyright law in Indonesia. The object of the study is a theater script adapted by the director in a theater performance in Yogyakarta. The formulation of the problem posed in this research is, how is the legal protection for the copyright of theater scripts that are adapted by the director in theater performances according to the Copyright Law? This study applies normative method that uses statutory and conceptual approach. The result of the study concludes that theater scriptwriters should have legal protection for their scripts that are adapted into theater performances. There are a number of factors that influence the legal protection of a written text adapted into a theater performance, namely the legal regulations, law enforcement factors, and cultural factors.
\end{abstract}

Key Words: Copyrights; legal protection; theatre script; theatre performance

\begin{abstract}
Abstark
Studi ini bertujuan untuk menganalisis pelindungan hukum hak cipta di Indonesia. Objek kajian yang diteliti adalah naskah teater yang diadaptasikan oleh sutradara dalam suatu petunjukan teater di Yogyakarta. Rumusan masalah yang diajukan dalam penelitian ini yaitu, bagaimana pelindungan hukum atas hak cipta naskah teater yang diadaptasi oleh sutradara dalam pertunjukan teater menurut Undang-Undang Hak Cipta? Penelitian yang menggunakan metode normatif ini menggunaan pendekatan perundang-undangan dan konseptual. Hasil penelitian menyimpulkan bahwa seharusnya penulis naskah teater mendapat pelindungan hukum atas naskah ciptaannya yang diadaptasi ke dalam pertunjukan teater. Ada sejumlah faktor yang memengaruhi pelindungan hukum atas naskah ciptaan yang diadaptasi ke dalam pertunjukan teater, yakni faktor peraturan hukumnya, faktor penegak hukumnya, dan faktor kebudayaan.
\end{abstract}

Kata-kata Kunci: Hak cipta; naskah teater; pelindungan hukum; pertunjukan teater 


\section{Pendahuluan}

Wujud dalam penciptaan karya yang dilakukan oleh manusia dengan tingkat kreativitas dan inovasi yang tinggi berupa ilmu pengetahuan, karya seni dan sastra. Tentunya memiliki nilai kemanfaatan untuk kehidupan manusia dalam hidup bermasyarakat. Untuk menghargai dari hasil ciptaan suatu karya yang tercipta dengan proses kreativitas dan inovasi yang sangat tinggi, serta banyak memakan waktu, fikiran, tenaga dan biaya. Maka perlu ada ketentuan yang mengatur hak mereka ketika telah menciptakan suatu karya. Dari sudut pandang tersebut, dikembangkan suatu ketentuan hukum yang dapat mendorong penelitian dan pengembangan dengan memberikan perlindungan bagi karya baru yang tercipta selama waktu tertentu oleh pencipta, dengan memberikan hak eksklusif bagi para pengembang seperti Hak Kekayaan Intelektual (selanjutnya disingkat HAKI). ${ }^{1}$

Masyarakat internasional khususnya yang tergabung dalam perundinganperundingan yang diselenggarakan atas prakasa forum General Agreement of Tariffs and Trade (selanjutnya disingkat GATT), pada tahun 1994 telah menyepakati suatu perjanjian internasional yang mengatur substansi-substansi HAKI dikaitkan dengan perdagangan internasional pada umumnya. ${ }^{2}$ Indonesia merupakan salah satu negara yang ikut andil dalam persetujuan perjanjian internasional tersebut pada hasil akhir putaran yang dilaksanakan di Uruguay. Konsekuensinya, Indonesia harus berusaha menegakkan prinsip-prinsip pokok yang terkandung dalam GATT termasuk di dalamnya mencangkup Trade Related Aspects of Intellectual Property Rights (TRIPs), yaitu Trade Related Aspects of Intellectual Property Rights Including Trade in Counterfeit Goods /TRIPs (aspek-aspek dagang yang terkait dengan Hak Atas Kekayaan Intelektual termasuk perdagangan barang palsu). ${ }^{3}$ Sedangkan dalam pelaksanaanya, aspek-aspek yang berkaitan dengan HAKI memiliki prinsip pokok tertentu yang terkandung. Prinsip-prinsip pokok yang terkandung dalam persetujuan TRIPS ${ }^{4}$, antara lain penulis uraian sebagai berikut.

a. Menetapkan standar minimum untuk perlindungan dan penegakan hukum HAKI di negara-negara peserta. Dengan demikian, negara peserta

${ }^{1}$ Sujud Margono, Hukum Cipta Indonesia Teori dan Analisis Harmonisasi Ketentuan World Trade Organization (WTO)-TRIPs Agreement, Ghalia Indonesia, Bogor, 2010, hlm. 3

2 Ibid., hlm. 5

3 Muhammad Djumhana dan R. Djubaedillah, Hak Milik Intelektual Sejarah, Teori dan Praktiknya di Indonesia, PT.Citra Aditya Bakti, Bandung, 2003, hlm. 18.

4 A. Zen Umar Purba. Menyambut Millenium III: TRIPs, Dimensi HAKI dan Kesipan Kita, Newsletter No. 39 X (Desember 1999), hlm. 2. Dilihat dari buku Sujud Margono, Hukum Cipta Indonesia Teori dan Analisis Harmonisasi Ketentuan World Trade Organization (WTO)-TRIPs Agreement. Ghalia Indonesia, Bogor, 2010, hlm. 5 
bisa menetapkan standar yang lebih tinggi selama hal tersebut tidak bertentangan dengan persetujuan TRIPS.

b. Negara-negara peserta diharuskan memberikan perlindungan HAKI yang sama kepada warga negara peserta lainnya. Apapun hak yang diberikan kepada warga negaranya, juga harus diberikan pada warga negara yang lain.

Persetujuan TRIPs memuat ketentuan mengenai penegakan hukum yang ketat disertai dengan mekanisme penyelesaian perselisihan sengketa (dengan adanya Dispute Settlement Body), yang diikuti dengan hak bagi negara yang dirugikan untuk mengambil tindakan balasan di bidang perdagangan secara silang (cross-relatiatory measures). Persetujuan TRIPs merupakan hasil kesepakatan Internasional yang paling komperhensif dalam bidang HAKI, yang juga merupakan perpaduan dari prinsip-prinsip dasar GATT dengan ketentuanketentuan internasional untuk perlindungan HAKI dalam suatu kerangka aturan hukum multilateral. ${ }^{5}$

Menurut Pasal 1 angka 1 Undang-Undang Nomor 28 Tahun 2014 tentang Hak Cipta, yang dimaksud tentang Hak Cipta adalah hak eksklusif pencipta yang timbul secara otomatis berdasarkan prinsip deklaratif setelah suatu ciptaan diwujudkan dalam bentuk nyata tanpa mengurangi pembatasan sesuai ketentuan perundang-undangan. ${ }^{6}$ Suatu hasil ciptaan yang didasari oleh kreativitas dan inovasi yang tinggi dan memiliki nilai, menjadi objek perlindungan yang dimiliki oleh pencipta. Pasal 1 angka 3 UU Hak Cipta menjelaskan bahwa pengertian ciptaan adalah setiap hasil karya cipta di bidang ilmu pengetahuan, seni dan sastra yang dihasilkan atas inspirasi, kemampuan, pikiran, imajinasi, kecekatan, keterampilan, atau keahlian yang di ekspresikan dalam bentuk nyata. ${ }^{7}$

Dari segi muatan, Hak Cipta mengandung esensi monopoli atas Hak Ekonomi atau Economic Rights dan Hak Moral atau Moral Rights. ${ }^{8}$ Dilihat dari pengertian tersebut esensi adanya Hak Ekonomi dan Hak moral yang diberikan oleh Hak Cipta adalah untuk melindungi kreativitas yang telah diciptakan dalam bentuk asli atau orisinil dari pencipta. Bertujuan untuk menghargai pribadi pencipta yang telah menciptakan karyanya berdasarkan kemampuan kreativitas dan inovasi dengan keahlian yang dimiliki sehingga karya tersebut dapat dilihat, didengar maupun dibaca.

\footnotetext{
${ }^{5}$ Sujud Margono, Hukum Cipta Indonesia..., Op. Cit., hlm. 6.

${ }^{6}$ Pasal 1 angka 1 Undang-Undang Nomor 28 Tahun 2014 tentang Hak Cipta

${ }^{7}$ Ibid.

${ }^{8}$ Hendry Soelistyo, Hak Cipta Tanpa Moral, Rajawali Pres, Jakarta, 2011, hlm. 13.
} 
Eksistensi Hak Cipta dalam kehidupan tentunya akan menyangkut banyak permasalahan, dalam segi teknologi, industri, sosial dan budaya. Maka melihat dari realita di kehidupan tersebut. Wujud dari hak cipta adalah adanya kepastian hukum untuk melindungi segala bentuk ciptaan yang terlahir dari ide kreatif dan inovasi dari setiap manusia. Hukum diharapkan dapat membantu untuk melindungi dan menyelesaikan sengketa ketika terjadi masalah dikemudian hari. Keberadaan hukum bertujuan menjamin kepastian hukum dalam masyarakat dan hukum harus pula bersendikan pada keadilan, yaitu asas-asas keadilan dari masyarakat itu. ${ }^{9}$

Ruang lingkup dalam hak cipta sangatlah beragam diantaranya adalah naskah teater. Proses penciptan teater tentu membutuhkan kreativitas dan inovasi setiap seniman penulis naskah. Dalam hal ini yang menjadi pokok kajian penulis adalah pertunjukan kesenian teater, yang dalam sebuah pertunjukan teater, peran seniman penulis naskah jarang dikenal oleh masyarakat umum. Kehadirannya tersilaukan oleh peran sutradara dan kemampuan aktor dalam memperankan naskah tersebut. Tetapi ketika mencoba mengamati lebih mendalam lagi, proses penulisan naskah sangatlah tidak mudah, karena cerita dan isi yang dibawakan menyajikan tentang proses kehidupan yang mengandung unsur agama, sosial, politik dan budaya, yang tentunya diperlukan pengalaman yang sangat ri'il dari seorang seniman dalam menuangkan ide kreatifnya sehingga menghasilkan suatu naskah. Dalam contoh naskah klasik, makna yang terkandung tidak terlepas dari pengaruh agama dan filsafat yang dipercaya oleh masyarakat, ketika diamati melalui tema, plot dan penokohan. ${ }^{10}$

Penanggung jawab dalam sebuah proses transformasi naskah ke bentuk pemanggungan adalah sutradara yang merupakan pimpinan utama kerja kolektif suatu pertunjukan teater. ${ }^{11}$ Kehadiran sutradara dituntut untuk memberikan suatu inovasi yang baru dalam sebuah naskah yang akan dipentaskan, sehingga sutradara sering melakukan adaptasi atas suatu naskah. Salah satu contoh adaptasi naskah oleh sutradara dalam pertunjukan teater, mengutip dari berita yang disajikan oleh JogjaReview.Net dalam sebuah pertunjukan teater, komunitas teater Topeng mempersembahkan sebuah pertunjukan berdasarkan kisah cinta sepasang kekasih yang tak lekang oleh waktu. Hanya Romeo dan Juliet yang bisa mengimbangi kisah itu. Sampek dan Engtay, legenda tentang cinta yang akhirnya terhubungan melalui keabadian. Pasangan romantis itu ditampilkan dalam

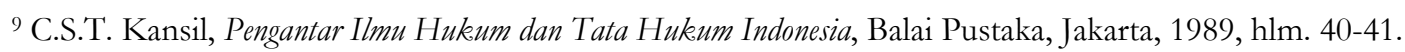

10 Yudiaryani, Panggung Teater Dunia Perkembangan dan Perubaban Konvensi, Pustaka Gondho Suli, Yogyakarta, 2002, hlm. 60.

11 Eko Santosa, dkk., Seni Teater Jilid 1., Direktorat Pembinaan Sekolah Menengah Kejuruan Direktorat Jenderan Manajeman Pendidikan Dasar dan Menengah Departemen Pendidikan Nasional, Jakarta, 2008, hlm. 44.
} 
sebuah pertunjukan teater dari sebuah naskah karya N. Riantiarno. Namun, mereka tidak tinggal di China pada malam itu. Sampek dan Engtay berpacaran di Jogjakarta. ${ }^{12}$ Dari pemikiran sutradara Azizi, adanya adaptasi yang mengubah karakter dan bentuk watak dalam pementasan, karena tokoh dalam karakter "Sampek Entay" diubah menjadi banyak banyolan dan komedi yang menghiasinya.

Adaptasi naskah adalah proses menafsirkan kembali suatu naskah, yang di dalamnya sudah terdapat pakem tertentu yang berdasarkan pengatahuan ilmu tentang budaya dan sosial atas naskah tersebut. Dalam kajian penulis mengenai adaptasi yang dilakukan oleh sutradara adalah adanya perubahan suatu karakter tokoh dan latar kejadian serta alur dalam suatu cerita naskah yang sama, tetapi ketika di pentaskan oleh sutradara menjadi berbeda. Tentunya dalam hal ini dapat menimbulkan pelanggaran dalam hal keaslian atau orisinalitas suatu naskah yang telah diciptakan oleh penulisnya. Dengan demikian, penulis mengkaji interaksi sosiologi hukum positif dalam penerapan Undang-Undang No. 28 Tahun 2014 tentang Hak Cipta terhadap pelaku seni khususnya seniman penulis naskah dan sutradara teater. Penelitian ini mengkaji eksistensi UU Hak Cipta dalam menyinergikan dua ruang yang memiliki tata cara dan ilmunya sendiri.

\section{Rumusan Masalah}

Berdasarkan uraian di atas, maka rumusan masalah yang dianalisis dalam penelitian ini adalah bagaimana pelindungan hukum atas hak cipta naskah teater yang diadaptasi oleh sutradara dalam pertunjukan teater menurut UndangUndang No. 28 Tahun 2014 tentang Hak Cipta?

\section{Tujuan Penelitian}

Adapun tujuan penelitian adalah untuk menganalisis perbuatan adaptasi naskah dalam pertunjukan teater yang dilakukan oleh sutradara menurut Undang-Undang No. 28 Tahun 2014 tentang Hak Cipta.

\section{Metode Pendekatan}

Penelitian ini merupakan penelitian hukum normatif yang didukung dengan data wawancara. Penelitian ini selain menggunakan sumber data

${ }_{12}$ Dikutip dari http://jogjareview.net/lensa/jika-sampek-dan-engtay-tinggal-di-jawa/ diakses pada kamis 26 Desember 2015. Pukul 23.10 WIB. Data Skripsi Penulis "Analisis Hak Cipta Naskah Teater yang dipertunjukan Komunitas Teater di Yogyakarta, FH. UII. 2015 
sekunder, yang terdiri atas bahan hukum primer yaitu Undang-Undang No. 28 Tahun 2014 tentang Hak Cipta dan bahan hukum sekunder berupa kepustakaan hukum yang terkait dengan hak kekayaan intelektual dan teori tentang efektivitas hukum, juga didukung dengan sumber data primer yang diperoleh dari wawancara. Penelitian ini menggunakan pendekatan perundang-undangan dan konseptual. Penelitian ini menganalisis Undang-Undang No. 28 Tahun 2014 tentang Hak Cipta dan sumber hukum yang mempengaruhinya secara deskriptifkualitatif.

\section{Hasil Penelitian dan Pembahasan}

Hukum dalam penerapanya selalu berkembang mengikuti realita sosial dan keadaan zaman. Pengembangan konsepsi hukum ini, bila dilihat dari segi usaha untuk mendorong tumbuhnya sikap dan budaya menghormati atau menghargai jerih payah atau hasil karya orang lain memiliki arti yang penting. ${ }^{13}$ Hukum dalam penerapanya juga memiliki fungsi sebagai sarana pembangunan, yang mampu melindungi hak setiap warga negara. Hak Cipta dalam perkembangan hukum di Indonesia memiliki proses sejarah yang panjang. Indonesia baru memiliki Undang-Undang tentang Hak Cipta pada 1982. UU tentang Hak Cipta merupakan sarana pembangunan hukum nasional setelah Indonesia meratifikasi TRIPs Agreemnet, yang keberadaannya dapat menjadi tonggak era pembangunan sistem Hak Kekayaan Intelektual di Indonesia. Meski bernuansa monopoli dan berkarakter individualistik, kelahiran UU Hak Cipta nyaris tanpa reaksi pro dan kontra. ${ }^{14}$

Penerapan suatu undang-undang tentunya tidak terlepas dari segi budaya hukum yang terdapat di Indonesia. Hal ini mengingat nilai semangat gotong royong dan budaya saling memberi telah melekat pada masyarakat. Pengembangan dan konsepsi pengaturan Hak Cipta secara pragmatis dianggap tidak kondusif dan bahkan berseberangan dengan upaya mencerdaskan anak bangsa, karena dinilai perlunya konsep "kebebasan" dalam memanfaatkan ciptaan secara cuma-cuma guna membantu pendidikan anak bangsa agar pandai cerdas dan berbudaya. ${ }^{15}$

Undang-Undang Hak Cipta dalam perjalanannya mengalami revisi sebanyak empat kali guna untuk menjawab semua permasalahan yang ada. Berawal dari Undang-Undang No. 6 Tahun 1982 tentang Hak Cipta sebagaimana telah diubah dengan Undang-Undang No. 7 Tahun 1987, kemudian diubah lagi

13 Sujud Margono, Hukum Cipta Indonesia Teori dan Analisis Harmonisasi Ketentuan World Trade Organization (WTO)-TRIPs Agreement, Ghalia Indonesia, Bogor, 2010, hlm. 51.

${ }^{14}$ Hendry Soelistyo, Hak Cipta Tanpa Hak Moral, Rajawali Pres, Jakarta, 2011, hlm. 45.

15 Ibid., hlm. 45-46. 
dengan Undang-Undang No. 12 Tahun 1997. UU Hak Cipta kemudian direvisi lagi menjadi Undang-Undang No. 19 Tahun 2002, dan yang terakhir saat ini berlaku adalah Undang-Undang No. 28 Tahun 2014 tentang Hak Cipta. Pengaturan hukum Hak Cipta dalam hukum nasional termasuk dalam bidang hukum perdata dan merupakan hukum benda. Pengertian benda atau zaak adalah benda berwujud atau benda tidak berwujud dalam Hukum Perdata. Hak kebendaan terdiri atas hak kebendaan materiil dan hak kebendaan immateriil, termasuk dalam hak kebendaan immateriil adalah Hak Kekayaan Intelektual (Intellectual Property Right) yang terdiri atas Hak Cipta (copyrights) dan hak milik industri (industrial property right). ${ }^{16}$

Adapun standar agar dinilai sebagai Hak Cipta (sandart of copyright ability) atas karya cipta di bidang ilmu pengetahuan, seni dan sastra yaitu: ${ }^{17}$ perwujudan (fixation) suatu karya cipta, keaslian (originality) atas suatu sifat karya cipta, dan kreativitas (creativity) yang mendasari pada proses kreatif suatu karya ciptaan. Undang-Undang Hak Cipta bertujuan untuk melindungi kreativitas seseorang dalam setiap ciptaannya yang berwujud ilmu pengetahuan, seni dan sastra, juga bertujuan sebagai penghargaan serta pengakuan terhadap karya cipta seseorang. Pada dasarnya konsepsi kesadaran Hak Cipta berkaitan dengan nilai sportivitas yang membuat orang senantiasi menghargai segala bentuk prestasi orang lain, maka salah satu fungsi Hak Cipta adalah pelindungan hukum melalui penyadaran kepada masyarakat.

Manusia yang berfikir dan mempunyai daya kreativitas sangat tinggi sering kali menemukan sesuatu dalam eksperimennya kemudian menghasilkan suatu karya bahkan bermanfaat untuk masyarakat umum. Untuk melindungi proses kreatif yang telah dilakukan oleh seseorang dalam menciptakan suatu ciptaan maka diaturlah mengenai Hak Cipta. Hak Cipta demikian orang Indonesia menyebutnya adalah hak yang tidak bisa dicabut dan diberikan oleh UndangUndang kepada pencipta atau ahli warisnya atau instansi lain yang dijamin oleh Undang-Undang. ${ }^{18}$

Sophar Maru Hutagalung juga mengemukakan pendapatnya tentang Hak Cipta. Hak Cipta sebagai hasil karya pencipta dalam bentuk khas apa pun juga dalam lapangan ilmu pengetahuan, seni dan sastra dari seseorang pencipta atau beberapa orang secara bersama-sama atas inspirasi lahirnya suatu ciptaan,

16 Budi Agus Riswandi dan M. Syamsudin, Hak Kekayaan Intelektual Dan Budaya Hukum, Rajawali Pres, Jakarta, 2005, hlm. 197.

${ }^{17}$ Ibid., hlm. 198.

${ }_{18}$ Rooseno Harjowidigdo, Perjanjian Lisensi Hak Cipta Musik Dalam Pembuatan Rekaman. Perum Percetakan Negara RI, Jakarta, 2005, hlm. 7. 
berdasarkan kemampuan pikiran, imajinasi, kecekatan, ketrampilan atau keahlian yang dituangkan dalam bentuk yang khas dan bersifat pribadi yang mendapat perlindungan hukum. ${ }^{19}$

Dalam kaidah ilmu hukum, Hak Cipta tegolong dalam Hak Kekayaan Intelektual digolongkan sebagai hak khusus atau eksklusif. Karena hak tersebut hanya diberika kepada pemilik atau pemegang hak yang bersangkutan untuk dalam waktu tertentu memperoleh perlindungan hukum guna mengumumkan, memperbanyak, mengedarkan, dan lain-lain hasil karya ciptanya atau memberi izin kepada orang lain untuk melaksanakannya. ${ }^{20}$ Menurut ketentuan Undangundang Hak Cipta Baru Tahun 2014 Pasal 1 butir 1 :

"Hak Cipta adalah hak eksklusif pencipta yang timbul secara otomatis berdasarkan prinsip deklaratif setelah suatu ciptaan diwujudkan dalam bentuk nyata tanpa mengurangi pembatasan sesuai dengan ketentuan peraturan perundang-undangan"

Upaya untuk memahami dalam penerapan Hak Cipta dapat dilakukan dengan mengenali objeknya. Objek hak cipta adalah segala bentuk ciptaan yang bermuatan ilmu pengetahuan, berbobot seni, dan bernuansa sastra. Ketiga ruang lingkup tersebutlah yang menjadi objek pelindungan Hak Cipta. Namun objek yang mendapatkan pelindungan hanya suatu ciptaan yang bersifat orisinil saja atau bukan hasil peniruan. ${ }^{21}$

Hak Cipta sebagai suatu hak eksklusif mengandung dua unsur esensi hak: yaitu hak moral (moral rights) dan hak ekonomi (economic rights). Hak moral adalah hak-hak yang melindungi kepentingan pribadi si pencipta yang menyangkut reputasinya sedangkan hak ekonomi diartikan seabagai hak yang dipunyai oleh si pencipta untuk mendapatkan manfaat ekonomi. ${ }^{22}$ Pasal 4 Undang-Undang No. 28 Tahun 2014 tentang Hak Cipta juga mengatur mengenai hak moral dan hak ekonomi, termasuk dalam hak eksklusif yang dimiliki oleh pencipta.

Wujud dari objek yang mendapatkan perlindungan dari Hak Cipta adalah suatu ciptaan, yang dalam Undang-Undang No. 28 Tahun 2014 tentang Hak Cipta dijelaskan dalam Pasal 1 angka 3 yang berbunyi sebagai berikut:

"Ciptaan adalah setiap hasil karya cipta di bidang ilmu pengetahuan, seni, dan sastra yang dihasilkan atas inspirasi, kemampuan, pikiran, imajinasi, kecekatan, keterampilan, atau yang diekspresikan dalam bentuk nyata."

${ }_{19}$ Shopar Maru Hutagalung, Kedudukan Hak Cipta dan Perannya dalam Pembangunan, Sinar Grafika, Jakarta, 2011, hlm. 126.

${ }^{20}$ Ibid., hlm. 51-52.

${ }^{21}$ Hendry Soelistyo, Hak CiptaTanpa Moral..., Op. Cit., hlm. 46.

22 Budi Agus Riswandi dan M. Syamsudin, Hak Kekayaan Intelektual..., Op. Cit., hlm. 3-4. 
Berdasarkan pengertian ciptaan di atas, Undang-Undang No. 28 Tahun 2014 tentang Hak Cipta juga mengatur mengenai ruang lingkup yang dilindungi. Pasal 40 ayat (1) Undang-Undang No. 28 Tahun 2014 tentang Hak Cipta menentukan, bahwa "Ciptaan yang dilindungi meliputi Ciptaan dalam bidang ilmu pengetahuan, seni, dan sastra terdiri atas :

a. Buku, pamflet, perwajahan karya tulis yang diterbitkan, dan semua hasil karya tulis lainya.

b. Ceramah, kuliah, pidato, dan Ciptaan sejenis lainya.

c. Alat peraga yang dibuat untuk kepentingan pendidikan dan ilmu pengetahuan.

d. Lagu dan/atau musik dengan atau tanpa teks.

e. Drama, drama musikal, tari koreografi, pewayangan dan pantomim.

f. Karya seni rupa dalam segala bentuk seperti lukisan, gambar, ukiran, kaligrafi, seni pahat, patung atau kolase.

g. Karya seni terapan.

h. Karya arsitektur.

i. Peta

j. Karya seni batik atau motif lain.

k. Karya fotografi.

1. Potret.

m.Karya senimatografi.

n. Terjemahan, tafsir, saduran, bunga rampai, basic data, adaptasi, aransemen, modifikasi dan karya lain hasil dari transformasi.

o. Terjemahan, adaptasi, aransemen, transformasi, atau modifikasi ekspresi budaya tradisional.

p. Kompilasi Ciptaan atau data, baik dalam format yang dapat dibaca dengan Progam Komputer maupun media lainnya.

q. Kompilasi ekspresi budaya tradisional selama kompilasi tersebut merupakan karya yang asli.

r. Permainan vidio.

s. Progam Komputer."

Berkaitan dengan ciptaan dalam bentuk terjemahan, tafsiran, saduran ataupun karya lain hasil dari transformasi, proses pelindungannya sebagai ciptaan tersendiri dan tidak mengurangi Hak Cipta atas ciptaan aslinya. Hal ini sebagaimana telah diatur dalam Pasal 40 ayat (2 dan 3) Undang-Undang No. 28 Tahun 2014 tentang Hak Cipta. Tentu saja dalam proses pelindungan suatu karya cipta dengan sifat orisinilnya yang mendapatkan pelindungan dalam suatu ciptaan.

Peran Naskah lakon dalam pertunjukan teater di Indonesia menjadi salah satu ciri utama akan keindahan bahasa Indonesia. Melihat perkembangan tersebut Naskah dilahirkan atau lahir bersama sastra dan bahasa Indonesia 
sebagai salah satu wujud dari semangat kebangsaan dan kebudayaan Indonesia. Dari mulai Rustam Effendi sampai Akhudiat umumnya pengarang naskah lakon sandiwara adalah para sastrawan dan pecinta bahasa Indonesia. Bahkan tokohtokoh utama dalam penulisan naskah lakon sandiwara bahkan perfilman adalah seniman sastra seperti: Sanoesi Pane, Usman Ismail, El Hakim, Utuy Tatang Sentani, WS Rendra, Sitor Situmorang, Asrul Sani dan banyak lagi nama seniman serta sastrawan penulis naskah angkatan terdahulu. ${ }^{23}$

Naskah dalam sebuah pertunjukan teater menjadi ruh yang mampu menghidupkan suatu karya seni yang divisualkan. Karena dalam sebuah panggung pertunjukan naskah dengan kuatnya mampu memainkan bahasa benda dan tubuh, yang kehadiranya sangat berpengaruh dalam bangunan suatu pertunjukan. ${ }^{24}$

Peran sutradara dalam pemilihan naskah tentunya terdapat proses kreatif tersendiri, dan dalam kajian yang dilakukan oleh penulis, kebiasaan yang sering terjadi dalam suatu pertunjukan seringkali sutradara memilih naskah yang divisualkan merupakan naskah orang lain. Kegiatan ini dalam sebuah proses kreatif naskah tersebut mengalami pengapdatasian, pengeditan dan periversian atas isi dan kandungan naskah. Sebagaimana kajian yang dilakukan oleh penulis mengenai naskah yang diadaptasi dan dipentaskan oleh sutradara, karena dalam dunia seni teater hal ini sering dilakukan oleh komunitas teater di Yogyakarta.

Seperti yang dikemukakan oleh Eko Santosa, ia mengatakan "ketika naskah telah terpilih, sutradara melakukan pengadaptasian naskah, dengan melakukan perubahan naskah namun tidak secara keseluruhan perubahan dalam bentuk adaptasi meliputi nama tokoh, lokasi kejadian, istilah-istilah gaya bahasa, serta kebudayaan".25 Dalam dunia pertunjukan teater di Yogyakarta tercatat banyaknya komunitas teater yang dalam pertunjukannya melakukan pengadaptasian naskah, hal ini disebabkan karena melihat latar belakang naskah dibuat dengan melihat realita sosial yang ada di era sekarang.

Salah satu contoh adaptasi naskah oleh sutradara dalam pertunjukan teater pada sabtu, 27 Desember 2014 mengutip dari berita yang disajikan oleh JogjaReview.Net dalam sebuah pertunjukan teater. Komunitas teater Topeng mempersembahkan sebuah pertunjukan berdasarkan kisah cinta sepasang kekasih yang tak lekang oleh waktu. Hanya Romeo dan Juliet yang bisa

${ }^{23}$ Kumpulan pikiran Arifin C Noer. Afrizal Malna, Agus Ley-loor..., Op. Cit., hlm. 4-5.

${ }^{24}$ Radhar Panca Dahana, Teater Dalam Tiga Dunia, Kementerian Pendidikan dan Kebudayaan Direktorat Jendral Kebudayaan, Jakarta, 2012, hlm. 88.

25 Wawancara langsung dengan Eko Santosa, praktisi dan sutradara teater di PPPPTK Jl. Kaliurang km 12 Sleman. Pada Selasa, 15 September 2015. (Data Skripsi Penulis "Analisis Hak Cipta Naskah Teater yang dipertunjukan Komunitas Teater di Yogyakarta, FH. UII. 2015) 
mengimbangi kisah itu. Sampek dan Engtay, legenda tentang cinta yang akhirnya berhubungan melalui keabadian. Pasangan romantis itu ditampilkan dalam sebuah pertunjukan teater dari sebuah naskah karya N. Riantiarno. Namun, mereka tidak tinggal di China pada malam itu. Sampek dan Engtay berpacaran di Jogjakarta. ${ }^{26}$ Dalam sebuah pertunjukan tersebutlah sutradara yang bernama Azizi, melakukan adaptasi yang mengubah karakter dan bentuk watak dalam pementasan, karena tokoh dalam karakter "Sampek Entay" tersebut diubah menjadi banyak banyolan dan komedi yang menghiasinya.

Pendapat lain terkait adaptasi naskah juga dikemukakkan oleh Putut Buchori yang notabene sebagai penulis naskah dan pegiat teater. Ia mengatakan "mengadaptasi naskah merupakan hak sutradara, namun sutradara juga harus memiliki wawasan yang luas untuk mengadaptasi, karena isi yang terkandung dalam naskah tidak semenah-menah untuk dihilangkan meski berbentuk kalimat candaan. Sutradara yang berwawasan, bentuk penafsirannyapun dapat dianggap suatu bentuk pelebaran penggarapan pertunjukan. Dalam sebuah pertunjukan kelompok teater yang menggunakan naskah orang lain pasti melakukan adaptasi. Akan dilakukan penyesuaian karakter, genre, pengadaptasian untuk dapat disesuaikan dengan kalangan umur aktor. Namun, sangat tidak etis jika pertunjukan tersebut mendapatkan keuntungan yang banyak bahkan para aktor dan yang lainnya mendapatkan upah yang cukup besar sedangkan bagi penulis tidak mendapatkan apapun bahkan bentuk permintaan izin mempertunjukan naskahnya".27 Dari pernyataan tersebutlah dalam proses adaptasi naskah sutradara harus mampu menghargai dan menghormati hak penulis naskah, walaupun sutradara dalam proses kreatif memiliki cara sendiri dalam penafsirannya, namun sudah ada ketentuan undang-undang yang mengatur tentang pelindungan hukum terhadap Hak Cipta.

Melihat realita sosial yang sering terjadi ketika dalam sebuah pertunjukan teater membawakan naskah orang lain, serta mencermati ketentuan UndangUndang Hak Cipta, maka si pencipta naskah berhak atas orisinalitas naskah tersebut. Hak Ekonomi dalam setiap Undang-Undang Hak Cipta selalu berbeda, baik teknologinya, jenis hak yang diliputinya dan ruang lingkup dari setiap jenis

${ }^{26}$ Dikutip dari http://jogjareview.net/lensa/jika-sampek-dan-engtay-tinggal-di-jawa/ diakses pada Senin 27 September 2015. Pukul 00.28 WIB. Data Skripsi Penulis "Analisis Hak Cipta Naskah Teater yang Dipertunjukan Komunitas Teater Di Yogyakarta, FH. UII. 2015

27 Wawancara langsung dengan Puthut Buchori, seniman penulis dan pegiat teater, di Rumahnya. Jum'at 11 September 2015. (Data Skripsi Penulis “Analisis Hak Cipta Naskah Teater yang Dipertunjukan Komunitas Teater Di Yogyakarta, FH. UII. 2015) 
Hak Ekonomi tersebut. Secara umum, setiap negara minimal mengenal dan mengatur Hak Ekonomi yang meliputi salah satunya Hak Adaptasi. ${ }^{28}$

Sedangkan langkah sutradara yang harus dilakukan ketika mengambil naskah orang lain seharusnya meminta izin dan pembagian atas Hak Ekonomi ketika pertunjukan tersebut dikomersialkan. Sedangkan untuk kepentingan edukasi yang tidak berorientasi keuntungan, kesenian dan kebudayaan cukup meminta izin atau mengabarkan kepada penulis jika penulis belum wafat, sementara jika penulis sudah wafat cumup mengabarkan kepada ahli warisnya. ${ }^{29}$

Hal sedana juga diutarakan oleh Rendra, sutradara muda dan juga aktor yang aktif di teater Gandrik, dalam wawancara dengan penulis mengatakan “etika penggunaan naskah untuk suatu pertunjukan seyogianya memintah izin, pamit, serta menanyakan tentang isi naskah lebih mendalam kepada penulis naskah. Seperti halnya yang pernah terajarkan perilaku kebudayaan bangsa Indonesia. Meminta izin merupakan sesuatu kebutuhan dapur kepada para tetangga. Hal ini memang sangat berbeda dengan konsep hak cipta menurutnya, melainkan tentang apa yang terkandung dalam isi tersebut. Bahwasanya budaya negeri ini adalah budaya tegur sapa dan guyub terhadap satu dengan yang lain. Berbeda dengan negara luar khususnya Amerika yang lebih individual dalam kehidupan". ${ }^{30}$

Mengingat naskah teater merupakan salah satu ciptaan yang dilindungi dalam Undang-Undang Hak Cipta, Hak Cipta adalah hak eksklusif pencipta yang timbul secara otomatis berdasarkan prinsip deklaratif setelah suatu ciptaan diwujudkan dalam bentuk nyata tanpa mengurangi pembatasan sesuai dengan ketentuan peraturan perundang-undangan.

Memiliki hak esklusif naskah yang diadaptasi oleh seniman, maka hak cipta penulis naskah selaku pencipta tidak bisa dicabut dan diberikan oleh UndangUndang kepada pencipta atau ahli warisnya atau instansi yang dijamin oleh undang-undang. ${ }^{31}$ Mencermati ketentuan Undang-Undang Hak Cipta, dalam praktik adaptasi naskah sebelum masuk ke ranah pertunjukan tentunya harus ada pengetahuan khusus yang dimiliki sutradara terkait naskah tersebut. Sutradara juga harus mengetahui latar belakang terciptanya naskah tersebut.

${ }^{28}$ Shopar Maru Hutagalung, Kedudukan Hak Cipta dan Perannya dalam Pembangunan, Sinar Grafika. Jakarta, 2011, hlm. 336.

${ }^{29}$ Wawancara langsung dengan Eko Santosa, praktisi dan sutradara teater di PPPPTK Jl. Kaliurang km 12 Sleman. Pada Selasa, 15 September 2015. (Data Skripsi Penulis "Analisis Hak Cipta Naskah Teater yang Dipertunjukan Komunitas Teater Di Yogyakarta, FH. UII. 2015)

30 Wawancara langsung dengan Rendra Bagus Pamungkas, Aktor dan Sutradara Muda Teater, di Sanggar Kelas Pagi Jogja. Pada Kamis, 10 September 2015 (Data Skripsi Penulis “Analisis Hak Cipta Naskah Teater yang Dipertunjukan Komunitas Teater Di Yogyakarta, FH. UII. 2015)

${ }^{31}$ Rooseno Harjowidigdo, Perjanjian Lisensi Hak Cipta Musik Dalam Pembuatan Rekaman, Perum Percetakan Negara RI, Jakarta, 2005, hlm. 7. 
Kajian mengenai Hak Cipta dalam konteks perbuatan adaptasi naskah dalam pertunjukan teater tentunya membutuhkan multidisipliner bidang ilmu lain. Tidak hanya hukum positif yang mampu memandangnya melainkan tetap dibutuhkan kajian ilmu yang lain. Sosiologi hukum bertujuan untuk memberikan penjelasan terhadap praktik-praktik pembuatan undang-undang, penerapan dan peradilan. Sosiologi hukum juga mempelajari bagaimana praktik yang terjadi pada masing-masing bidang kegiatan hukum tersebut. Sosiologi hukum berusaha menjelaskan, sebab praktik yang demikian itu terjadi, faktor-faktor yang berpengaruh, latar belakangnya. Tujuan untuk memberikan penjelasan ini memang agak asing bagi studi hukum "konvensional" yang bersifat preskriptif yang hanya berkisar pada "apa hukumnya" dan "bagaimana menerapkannya". ${ }^{32}$

Untuk melihat interaksi hukum tersebut, teori yang penulis gunakan adalah menggunakan teori efektivitas hukum menurut Soerjono Soekanto. ${ }^{33}$ Efektif atau tidaknya suatu hukum ditentukan oleh 5 faktor, yaitu:

1. Faktor hukumnya sendiri (undang-undang).

2. Faktor penegak hukum, yakni pihak-pihak yang membentuk maupun menerapkan hukum.

3. Faktor sarana atau fasilitas yang mendukung penegakan hukum.

4. Faktor masyarakat, yakni lingkungan dimana hukum tersebut berlaku atau diterapkan.

5. Faktor kebudayaan, yakni sebagai hasil karya, cipta dan rasa yang didasarkan pada karsa manusia di dalam pergaulan hidup.

Lima faktor di atas digunakan untuk menemukan interaksi hukum positif dan sosiologi hukum guna menjawab praktik Undang-Undang Hak Cipta dalam pertunjukan teater. Mengingat bahwa penegakan hukum bukanlah semata-mata pelaksanaan undang-undang, walaupun di dalam kenyataan di Indonesia kecenderungannya adalah demikian, sehingga pengertian law enforcement begitu popoler. ${ }^{34}$ Apalagi dalam Undang-Undang Hak Cipta masih kurang detail mengatur tentang karya sastra dalam pertunjukan teater. Walaupun dalam praktiknya sering ditemukan pelanggaran Hak Cipta namun sudah menjadi sebuah kebiasaan dalam komunitas Teater untuk menginterpretasikan sebuah naskah.

Hal di atas dikarenakan naskah merupakan obyek seni yang perlu dilakukan penalaran ulang. Sehingga dalam kebiasaan yang diterapkan oleh kalangan seniman teater belum terjawab dalam Undang-Undang Hak Cipta.

${ }^{32}$ Satjipto Raharjo. Ilmu Hukum, PT. Citra Aditya Bakti, Bandung, Cetakan Ke 8, 2014, hlm. 372.

33 Soerjono Soekanto, Faktor-faktor yang Mempengarubi Penegakan Hukum, PT. Raja Grafindo Persada, Jakarta, 1983, hlm. 8.

${ }^{34}$ Ibid., hlm. 7. 
Mengingat Undang-Undang Hak Cipta Indonesia lahir guna memenuhi kebutuhan hukum negara setelah meratifikasi perjanjian Internasional khususnya yang tertuang dalam TRIPs. Namun esensi diberlakukannya hukum negara tentu harus memperhatikan hukum lokal, yang tidak melepaskan nilai filosofis, sosiologis dan yuridis yang telah terbangun oleh budayanya.

Interaksi hukum yang terjadi dalam Hak Cipta dikaji dalam penelitian ini dengan menggunakan pendekatan teori efektivitas hukum menurut Soerjono Soekamto. Kajian dilakukan terhadap perbuatan adaptasi naskah teater yang dipertunjukkan komunitas teater. Namun, dari 5 faktor dalam teori efektivitas hukum, penulis merumuskan ke dalam 3 faktor yang ditemukan dan menghasilkan tinjauan:

\section{Faktor Hukum (undang-undang)}

Mengenai dasar hukum tentang Hak Cipta telah diatur dalam UndangUndang No. 28 Tahun 2014, yang tujuannya adalah agar Undang-Undang tersebut mempunyai dampak positif, artinya supaya Undang-Undang tersebut mencapai tujuan, sehingga efektif. ${ }^{35}$ Disatu sisi, sangat disayangkan jika peraturan yang telah ditetapkan bukan semata-mata keniatan bagi penegak hukum untuk menetapkan. Bentuk UU yang tidak hanya sebagai pembentukan untuk menyambut kehadiran pasar bebas semestinya didasari dengan keseriusan pemerintah untuk mengelola pelindungan hak bagi pencipta suatu karya dari regional daerah hingga tingkat nasional.

Sedangkan dengan karya seni yang bersifat lentur ini, seharusnya pemerintah dapat menentukan hak suatu pelindungan bagi pencipta penulis naskah jika tidak semua memiliki hak cipta. Karena kebudayaan sosiologi bangsa yang tidak semuanya untuk di perdagangkan namun lebih memilih dengan nilai sesrawung, dengan kenal, mengenalkan diri, akrab mengakrabkan diri. UU ini akan berlaku dan sesuai kelompok yang dipandang besar bahkan mampu memperdagangkan suatu karyanya. Sedangkan di Indonesia begitu banyak tersebar suatu kelompok, penulis naskah teater, seniman yang dapat disebut dengan kehidupan kesederhanaan. ${ }^{36}$

\section{Faktor Penegak Hukum}

Secara sosiologis makna penegakan hukum memiliki kedudukan (status) dan (role). Kedudukan (sosial) merupakan posisi tertentu di dalam struktur

35 Ibid., hlm. 11-12.

36 Wawancara langsung dengan Rendra Bagus Pamungkas, Aktor dan Sutradara Muda Teater, di Sanggar Kelas Pagi Jogja. Pada Kamis, 10 September 2015 (Data Skripsi Penulis “Analisis Hak Cipta Naskah Teater yang Dipertunjukan Komunitas Teater Di Yogyakarta, FH. UII. 2015) 
kemasyarakatan yang mungkin tinggi, sedang-sedang saja atau rendah. Kedudukan tersebut sebenarnya merupakan suatu wadah yang isinya adalah hak-hak dan kewajiban-kewajian tertentu. Suatu hak sebenarnya merupakan wewenang untuk berbuat atau tidak berbuat, sedangkan kewajiban adalah beban atau tugas. Seorang penegak hukum, sebagaimana halnya dengan warga negara masyarakat lainnya, mempunyai kedudukan dan peranan sekaligus. ${ }^{37}$ Namun dalam aturan hukum terkait Hak Cipta belum dilakukan secara proposional. Menurut Putut Buchori, "seharusnya Taman Budaya Yogyakarta dan Dirjen HKI selaku representasi dari Pemerintah melakukan sosialisasi kepada seniman penulis naskah, sutradara, kelompok teater dan masyarakat umum, tentang Hak Cipta dan penerapanya, karena dalam segi peraturannya ketika Hak Cipta ditegakkan tentu melindungi Ciptaan para seniman yang ada di Yogyakarta" ${ }^{38}$

\section{Faktor Kebudayaan}

Pembahasan faktor kebudayaan diketengahkan dengan masalah sistem nilai-nilai yang menjadi inti dari kebudyaan spiritual atau non-material. Sebagai suatu sub sistem dari sistem kemasyarakatan, maka hukum mencangkup struktur, subtansi dan kebudayaan. Struktur merupakan wadah ataupun bentuk sistem tersebut yang menyangkut lembaga-lembaga, hak-hak, serta kewajibankewajiban. Sedangkan subtansi mencakup isi norma-norma hukum beserta perumusannya maupun acara untuk menegakkannya yang berlaku bagi pelaksana hukum maupun proses peradilan. Kebudayaan sistem hukum pada dasarnya mencangkup nilai-nilai yang mendasari hukum yang berlaku, nilai-nilai yang merupakan konsepsi-konsepsi abstrak mengenai apa yang dianggap baik sehingga dianut dan apa yang dianggap buruk sehingga dihindari. ${ }^{39}$

Praktik interpretasi naskah teater sebagaimana wawancara dengan Rendra Bagus, sebagai berikut:

"Jika pada realitanya tentang etika penggunaan naskah untuk suatu pertunjukan memintah izin, pamit, serta menanyakan tentang isi naskah lebih mendalam. Juga sering dilakukan komunitas Teater dari tingkat SD, SMP, SMA, UKM Perguruan Tinggi, serta berbagai kelompok teater setiap daerah untuk meminta izin penggunaan naskah yang begitu sesuai bagi kebudayaan Negara Indonesia. Seperti halnya yang pernah terajarkan perilaku

${ }^{37}$ Soerjono Soekanto, Faktor-faktor yang Mempengarubi Penegakan Hukum..., Op. Cit., hlm. 19-21.

38 Wawancara langsung dengan Puthut Buchori, seniman penulis dan pegiat teater, di Rumahnya. Jum'at 11 September 2014. (Data Skripsi Penulis “Analisis Hak Cipta Naskah Teater yang Dipertunjukan Komunitas Teater Di Yogyakarta, FH. UII. 2015)

39 Soerjono Soekanto, Faktor-faktor yang Mempengarubi Penegakan Hukum, Op. Cit., hlm. 59-60. 
kebudayaan bangsa. Seperti, meminta izin sesuatu kebutuhan dapur kepada para tetangga. ${ }^{40}$

Hal senada juga dikemukakan oleh Eko Santoso, bahwa "seharusnya pengadaptasi naskah meminta izin dan pembagian atas Hak Ekonomi apabila pertunjukan tersebut dikomersialkan, sedangkan apabila untuk kepentingan edukasi nonprovit, kesenian dan kebudayaan maka cukup meminta izin atau mengabarkan kepada penulis jika penulis belum wafat dan ketika penulis sudah wafat mengabarkan kepada ahli warisnya". ${ }^{41}$

\section{Penutup}

Berdasarkan hasil penelitian dan pembahasan di atas, dapat disimpulkan bahwa seharusnya penulis naskah teater mendapat pelindungan hukum atas naskah ciptaannya yang diadaptasi ke dalam pertunjukan teater. Ada sejumlah faktor yang memengaruhi pelindungan hukum atas naskah ciptaan yang diadaptasi ke dalam pertunjukan teater, yakni faktor peraturan hukumnya, faktor penegak hukumnya, dan faktor kebudayaan. Adapun saran yang dapat penulis ajukan adalah perlunya pengaturan lebih detail mengenai pelindungan karya cipta seni pertunjukan teater berdasarkan konsep kultural bangsa Indonesia.

\section{Daftar Pustaka}

\section{Buku}

Dahana, Radhar Panca, Teater Dalam Tiga Dunia. Kementerian Pendidikan dan Kebudayaan Direktorat Jendral Kebudayaan, Jakarta, 2012.

Djumhana, Muhammad dan R. Djubaedillah, Hak Milik Intelektual Sejarah, Teori dan Praktiknya di Indonesia, PT. Citra Aditya Bakti, Bandung, 2003.

Hutagalung, Shopar Maru, Kedudukan Hak Cipta dan Perannya dalam Pembangunan. Sinar Grafika, Jakarta, 2011.

Kansil, C.S.T., Pengantar Ilmu Hukum dan Tata Hukum Indonesia, Balai Pustaka, Jakarta, 1989.

Margono, Sujud, Hukum Cipta Indonesia Teori dan Analisis Harmonisasi Ketentuan World Trade Organization (WTO)-TRIPs Agreement, Ghalia Indonesia, Bogor, 2010.

40 Wawancara langsung dengan Rendra Bagus Pamungkas, Aktor dan Sutradara Muda Teater, di Sanggar Kelas Pagi Jogja. Pada Kamis, 10 September 2015 (Data Skripsi Penulis “Analisis Hak Cipta Naskah Teater yang Dipertunjukan Komunitas Teater Di Yogyakarta, FH. UII. 2015)

${ }^{41}$ Wawancara langsung dengan Eko Santosa, praktisi dan sutradara teater di PPPPTK Jl. Kaliurang km 12 Sleman. Pada Selasa, 15 September 2015. (Data Skripsi Penulis “Analisis Hak Cipta Naskah Teater yang Dipertunjukan Komunitas Teater Di Yogyakarta, FH. UII. 2015) 
Raharjo, Satjipto, Ilmu Hukum, PT. Citra Aditya Bakti, Bandung, 2014.

Riswandi, Budi Agus dan M. Syamsudin, Hak Kekayaan Intelektual Dan Budaya Hukum, Rajawali Pres, Jakarta, 2005.

Rooseno, Harjowidgdo, Perjanjian Lisensi Hak Cipta Musik Dalam Pembuatan Rekaman, Perum Percetakan Negara RI, Jakarta, 2005.

Santosa, Eko. dkk., Seni Teater Jilid 1. Direktorat Pembinaan Sekolah Menengah Kejuruan Direktorat Jenderan Manajeman Pendidikan Dasar dan Menengah Departemen Pendidikan Nasional, Jakarta, 2008.

Soelistyo, Hendry, Hak CiptaTanpa Moral, Rajawali Pres, Jakarta, 2011.

Soekamto, Soerjono, Faktor-faktor yang Mempengaruhi Penegakan Hukum, PT. Raja Grafindo Persada, Jakarta, 1983.

Yudiaryani, M.A., Panggung Teater Dunia Perkembangan dan Perubahan Konvensi. Pustaka Gondho Suli, Yogyakarta, 2002.

\section{Hasil Penelitian / Tugas Akhir}

Skripsi Ahmad Muhsin, Analisis Hak Cipta Naskah Teater Yang Dipertunjukan Komunitas Teater Di Yogyakarta, FH. UII, 2015.

\section{Wawancara}

Wawancara langsung dengan Eko Santosa, praktisi dan sutradara teater di PPPPTK Jl. Kaliurang km 12 Sleman. Pada Selasa, 15 September 2015 “ yang diambil dari Skripsi Ahmad Muhsin. Analisis Hak Cipta Naskah Teater Yang Dipertunjukan Komunitas Teater Di Yogyakarta. FH. UII. 2015.

Wawancara langsung dengan Puthut Buchori, seniman penulis dan pegiat teater, di Rumahnya. Jum'at 11 September 2015 yang diambil dari Skripsi Ahmad Muhsin. Analisis Hak Cipta Naskah Teater Yang Dipertunjukan Komunitas Teater Di Yogyakarta. FH. UII. 2015.

Wawancara langsung dengan Rendra Bagus Pamungkas, Aktor dan Sutradara Muda Teater, di Sanggar Kelas Pagi Jogja. Pada Kamis, 10 September 2015 yang diambil dari Skripsi Ahmad Muhsin. Analisis Hak Cipta Naskah Teater Yang Dipertunjukan Komunitas Teater Di Yogyakarta. FH. UII. 2015 